\title{
THE EFECTS OF SETTLEMENT ON THE PREVALENCE OF Ascaris INFECTION IN TWO AMERINDIAN POPULATIONS OF THE BRAZILIAN AMAZON
}

\author{
Janet M. CHERNELA', Vernon E. THATCHER ${ }^{2}$
}

\begin{abstract}
Studies were made of the intestinal parasites of Amerindian populations of the Uaupes River basin of Brazil. Three groups were sampled: 1) Tukano fisher-agriculturalists who live in permanent riverine villages; 2) Maku hunter-horticulturalists who live in close contact with the Tukano fishing villages; and 3) Maku who inhabit the forest interior and have little contact with permanent settlements. Fecal samples were collected from 498 individuals of which 220 were from the first group, 135 from de second and 143 from the third. The samples were analyzed by means of microflotation and centrifugal sedimentation. A total of 18 protozoan and helminth species were recorded based on the presence of cysts or eggs. These included five nematode species that could not be identified. The three common pathogenic nematodes were found to be prevalent: the hookworm, Necator americanus $(96 \%)$; the whipworm, Trichuris trichiura (77\%) and the large roundworm, Ascaris lumbricoides (75\%). The prevalence of Ascaris among the villages was found to vary from 56 to $100 \%$. Individuals living in, or associated with, permanent settlements had higher prevalence and intensity rates than those living in the nomadic hunter-gatherer way. This is shown to be directly related to fecal contamination of the environment in and around permanent settlements. The prevalence of Ascaris in a population can be used as an indicator of such environmental contamination.
\end{abstract}

Key words: Ascaris, roundworms, parasites, helminths, indians.

O efeito de permanência sobre a prevalência de infecção por Ascaris em duas populacões de ameríndios da amazônia brasileira.

RESUMO - Estudos foram feitos dos parasitas intestinais de populações de amerindios da bacia do Rio Uaupes no Brasil. Três grupos foram amostrados: 1) Tukano pescadores-agricultores que vivem em aldeias ribeirinhas permanentes; 2) Maku caçadores-horticultores que vivem em contato próximo com as aldeias pescadoras dos Tukano; e 3) Maku que habitam o interior da selva e têm pouco contato com aldeias permanentes. Amostras fecais foram obtidas de 498 indivíduos dos quais 220 foram do primeiro grupo, 135 do segundo e 143 do terceiro. As amostras foram analisadas pelos métodos de microflutuação e por sedimentação centrífuga. Um total de 18 espécies de protozoários e helmintos foram assinaladas com base na presença de cistos ou ovos. Entre estas, cinco espécies de nematóides não puderam ser identificadas. As três espécies de nematóides patogênicas comuns foram prevalentes: Necator americanus (96\%); Trichuris trichiura (77\%) e Ascaris lumbricoides (75\%). A prevalência de Ascaris entre as aldeias variou entre 56 e $100 \%$. Indivíduos morando em, ou associados com, aldeias permanentes apresentaram taxas de prevalência e intensidade mais elevadas do que as pessoas que continuavam vivendo como caçadores nômades. Isto tem uma relação direta com a contaminação fecal do ambiente dentro e ao redor das aldeias permanentes. A prevalência de Ascaris numa população pode ser utilizada como uma indicadora deste tipo de contaminação ambiental.

Palavras-chave: Ascaris, vermes redondos, parasitas, helmintos, índios.

1 Associate Professor, Department of Sociology/Anthropology, Florida International University, North Miami, FL 33181 USA

2 Instituto Nacional de Pesquisas da Amazônia-INPA, Coordenação de Pesquisas em Biologia Aquática, Caixa Postal 478, 69011-970 - Manaus, Amazonas, Brasil.

ACTA AMAZONICA 23(1): 25-35. 1993. 


\section{INTRODUCTION}

Infestation with Ascaris lumbricoides, the common soil-transmitted nematode known as the round worm, is shown to be strongly related to settlement practices. A comparison of levels of Ascaris infection in three sub-groups of Amerindians in the Northwest Amazon region of Brazil demonstrates the dynamic interaction of parasite life-cycles and the cultural practices of the host population. The study reveals unusually high as well as low levels of infection within a single geographic sample inhabiting the Uaupes basin of Brazil. In addtion, the specimens reveal the highest percentage of unidentifiable helminth eggs of any study done on humans to date.

The findings here are relevant for several reasons. First, Ascaris infection is one of the world's major health hazards. It has been estimated to infect about one fourth of the world's population (PETERS \& GILLES, 1977). In 1979 , the annual global mortality from ascariasis (the disease produced by $A s-$ caris) was estimated to be 20,000 persons a year and the morbidity rate to be one billion cases a year (WALSH \& WARREN, 1979). Ascaris can cause a number of serious, and sometimes fatal, complications, such as: intestinal blockage, bile duct blockage, liver damage and rupture of the appendix.

In addition, the findings here are also relevant to development, issues. Wherever nomadic or semi-nomadic groups are brought into the reach of national cultures, they are made to limit their movements, and to resettle in permanent communities. Such efforts at change are likely to be accompanied by hazardous increases in diseases, such as ascariasis, if they are carried out in ignorance of available information.

\section{Ascaris lumbricoides}

Ascaris lumbricoides is the largest of the intestinal nematodes and the most common of all helminths parasitizing the human, intestine. Its eggs enter the human host by ingestion of dust, contaminated water, or food. Once within the host the second stage larvae penetrate the intestinal wall and enter the circulation where they migrate to the liver and later the lungs and the upper respiratory tract. The larvae migrating in the lungs can do a considerable amount of damage and produce symptoms, such as a cough. Fourteen days after infection, the larvae enter the throat and return to the alimentary tract where they mature. The adults usually reside in the jejunum and ileum of the host. The female lays an estimated 240.000 eggs per day over a period of approximaltely one year after which she dies. The eggs enter the environment in the feces of the host.

Since Ascaris eggs are discharged in the feces of infected individuals, the endemicity of this parasite depends upon habitual or continual re-contamination of the soil. The degree of infection in a population is therefore expected to be directly related to exposure and re-exposure to the eggs via their contact with contaminated soil. This contact is in turn related to settlement 
patterns and associated practices of hygene (defecation). The more time a population spends in a single location, the greater the incidence of a given soilborne parasite. Three characteristics of Ascaris make it a particularly useful indicator of ground contact contamination: 1) the relatively short life span of the sexually mature worm in the human host (one year); 2) the necessary role which soil plays in the life-cycle of the helminth; and 3) the ease with which the eggs can be found and identified in fecal samples.

\section{Geographic and Ethnographic Background}

The Uaupes River basin is located at the northwest extreme of the Amazon rainforest. The Uaupes, and its major tributary streams, the Papuri and Tiquie, flow southeasterly to enter the Rio Negro in Brazil at São Gabriel da Cachoeira. Rainfall in this region is the highest in Amazonia, with an average yearly rainfall of $3,743 \mathrm{~mm}$. The study was carried out on the Tiquie affluent of the Uaupes.

The Amerindians of the Uaupes basin in Brazil may be divided into two economically interdependent, but genetically distinct populations: 1) a population of fisher-agriculturalists who are sedentary and inhabit permanent riverine villages; and 2) a population of hunter-gatherers who until recently practiced a semi-nomadic lifestyle and lived in the interior of the forest. The first group may be referred to as Tukanoan which is the name of the family of languages spoken by most of these people. The second population is called Macuan in the literature, though this title encompasses at least four language groups.

The estimated 10,000 Tukano indians of the Uaupes inhabit permanent settlements situated at distances of 0.5 to $35 \mathrm{kms}$ from one another along the river bank. A village may consist of a large longhouse (as among the Bara of the Pira-Parana River; see HUGH-JONES, 1979) or several family residences situated around a common clearing or plaza, as among the Tukano of the Tiquie River, the population described here. Tiquie villages consist of approximately 5 to $10 \mathrm{mud}$ and daub houses with thatch roofs and dirt floors.

A Tukano sib conceives of itself as permanently placed on the longhouse site of its ancestors. Even when faced with resource stress signalled by diminishing garden yields or fishing disputes, a village is not moved. Rather, the population disperses through fissioning, with bud groups leaving the parent unit and establishing new sites. Settlements characteristically fraction at 150 persons, though a few villages have more than this number of residents. The parent village remains occupied by the remaining majority.

The Tukano indians subsist largely on root-crop cultivation and fishing, with a single nuclear family clearing up to 380 hectares of land for cultivation. Since maintaining this land requires a significant amount of labor, Tukano attempt to draw Maku hunting 
groups to assist in cultivation (CHERNELA, 1983).

The settlement patterns of the 1,700 Makuan indians estimated to inhabit the forested Uaupes interfluve (REID, 1979; SILVERWOOD-COPE, 1972) contrast markedly with those of the Tukano. As opposed to the large sedentary villages of the riverine Tukano, the population density of the interfluve Maku is scant, with campsites situated at great distances from one another. Local populations are small and group composition is flexible. Groups migrate between base settlements and three to six hunting camps. Camp sites are occupied for 3 to 5 days before the group moves to a new hunting location. Maku base camp houses are rebuilt annually from palm leaves or tree bark. Houses open in the direction of the forest and, unlike the Tukano, share no common plaza.

The Maku subsist on a broad spectrum of foods, including arboreal and terrestrial animals, insects, forest fruits and other non-domestic plants, and to a lesser extent, seasonal fishing and horticulture. When Maku do maintain gardens, these are small.

Traditionally, Maku bands and Tukano villages were paired in a mutualistic trade relationship, with Maku trading agricultural labor or meat for Tukano garden products or fish. These contractual relationships, though flexible, persisted over many generations.

Today, Maku-Tukano exchange relationships range from no or minimal contact to ongoing contact. In the former, contact is limited to short-term exchanges of river and forest resources. such as game for fish. In the latter, Maku set up base camps near Tukano villages, trading their labor in Tukano gardening and food preparation for processed agricultural products.

\section{MATERIAL AND METHODS}

\section{Population Studies}

Three sub-groups of this population were selected for study:

1) Tukano fisher-agriculturalists who inhabit permanent riverine villages; 2) Maku hunter-horticulturalists who live in close contact with these fishing villages; and 3) Makuan hunterhorticulturalists who live in the forest interior and have little contact with permanent river settlements.

Fecal samples were collected from 498 individuals in the region of the Tiquie and Uaupes Rivers in the northwestern portion of the Brazilian Amazon. Of the 498 individuals, 220 were Tukano, 135 Maku in contact wtih Tukano and 143 Maku with little or no contact with Tukano. This sample comprised all of the individuals of 12 villages, ranging in age from new-born to approximately 70 years of age. Data on demography, settlement paitern and diet were collected through interviews and observation. These data constitute part of a study of the indigenous populations of the Uaupes basin iniated in 1978 (see CHERNELA, 1983; 1985). 


\section{Field and Laboratory Techniques}

Fecal samples were collected in the field from every member of the study populations. A village wide meeting was held during which instructions were explained to a headman who then communicated them to his villagers. In addition, a temporary laboratory was created and villagers were encouraged to visit it to see the results of their tests and participate actively in the survey.

Each individual was provided with a small plastic bag marked in waterproof ink with a collection number and the donor's name. Stool specimens were collected within twelve hours of distribution (bags were distributed in the evening and collected the following morning). A fresh specimen was examined at the site and a fixed specimen prepared and sent to Manaus for laboratoty examination. In addition, sputum samples were collected from nine individuals.

Fresh material was prepared at the site by using a technique known as microflotation. A 50-100 mg sample was selected, placed on a microscope slide, mixed with a few drops of saturated sugar solution and triturated vigorously with toothpicks for 30 seconds. Hard objects, such as seeds and large fibers, were removed with a forceps. The remaining material was covered with a $22 \times 22 \mathrm{~mm}$. coverglass and left standing for 10 minutes. Helminth ova were counted by examining the preparation at $100 \mathrm{x}$ magnification while focusing the microscope at the level of the bottom of the coverglass. We have found that this method is better at clearing detritus than methods using glycerine (such as the Kato and Miura technique as described in MARTIN \& BEAVER, 1968) and is less damaging to hookworn eggs.

Preserved fecal samples were also prepared and sent by air to Manaus for laboratory analysis. The thimble-sized samples were fixed in a solution consisting of 85 parts of $85 \%$ alcohol, 10 parts of commercial formalin and 5 parts of glacial acetic acid (AFA). At the laboratory, samples of about 100 $\mathrm{mg}$ were rehydrated, screened through two layers of gauze and centrifuged at low speed for 30 seconds. After decanting the water in the centrifuge tube, the material in the tip of the tube was removed by pipette and placed on a microscope slide for examination. This method was found to be faster and more accurate than concentration by flotation or by formalin-ether sedimentation and it does not colapse hookworm eggs. This method permits the detection of infection levels as low as 10 eggs per gram (EPG).

Temporary fecal slides were also prepared for examination. AFA fixed feces normally have a $20-30 \%$ water content. Most of this water was removed by decanting the AFA and replacing it with $95 \%$ alcohol. A $50 \mathrm{mg}$ sub-sample was removed and transferred to a large drop phenol-fuchsin stain on a microscope slide. A coverglass was placed over the material and in 10-15 minutes the preparation was ready to be examined and the 
helminth ova counted.

A miniaturization of the HaradaMori filter paper tecnique was used to prepare microcultures of hookworn larvae which were then transported to Manaus for study. After smearing 200$300 \mathrm{mg}$ of fresh feces on a $15 \times 50 \mathrm{~mm}$ strip of filter paper, the latter was placed in an upright position in a 20 $\mathrm{ml}$ screw-capped bottle containing about $5 \mathrm{ml}$ of water. After 6 to 10 days, the living larvae were collected from the water by centrifugal concentration. The small bottles used with this method have the advantage of being less expensive than the test tubes used in the Harad-Mori technique. Also, they will stand upright on a flat surface, can be capped to limit airborn contamination and can be directly examined with a standard dissecting microscope. Cultures made in the field were flown 800 miles to the laboratory in Manaus with excellent results, and only a few sample were lost to fungal contamination.

\section{RESULTS}

\section{Helminth Parasite Survey}

Table 1 shows the results od stool examinatons for parasite cysts and ova in 498 individuals. Only 3 negative were found and all were infants under six months of age. A total of 18 parasitic protozoan and helminth species were recorded, of which five were not specifically identified. The maximum number of different species found in one individual was seven, with an av-
Table 1. Infection Rates of 13 Species of Intestinal Parasites in 498 Amazonian Amerindians from the Uaupes River, Brazil

\begin{tabular}{lc}
\hline Entamoeba coli & $63 \%$ \\
Entamoeba histolytica & 6.6 \\
Endolimax nana & 5 \\
lodamoeba butschlii & 12 \\
Enteromonas hominis & 3 \\
Chilomastix mesnili & 30 \\
Giardia lamblia & 5 \\
Balantidium coli & 6 \\
Necator americanus & 96 \\
Ascaris lumbricoides & 75 \\
Trichunis trichiura & 77 \\
Enterobius vermicularis & 6 \\
Strongyloides stercoralis & 3.5 \\
\hline
\end{tabular}

erage of four species per person. Three common parasite species were especially prevalent: the hookworm, Necator americanus (96\%); the whipworm, Trichuris trichiura ( $77 \%)$; and the roundworm, Ascaris lumbricoides (75\%). The protozoan species, Entamoeba coli $(63 \%)$ and Chilomastix mesnili $(30 \%)$, were found to be moderately prevalent. In addition, eight other intestinal parasites occurred with prevalence rates below $15 \%$ : Iodamoeba bütschlii (12\%); Entamoeba histolytica (6.6\%); Endolimax nana $(5 \%)$; Enteromona hominis (3\%); Giardia lamblia (5\%); Balantidium coli (6\%); Enterobius vermicularis (6\%); and Strongyloides stercoralis $(3.5 \%)$.

O nine sputum samples examined, one each contained eggs of Enterobius, Trichuris and Necator. This finding suggest that the individuals involved had been breathing dust contaminated with helminth ova.

A total of 79 ova found in fecal samples could not be placed within known species. The ova were measured 
and studied. These rare, unidentified nematode eggs were seen in fecal samples from 60 of 390 persons (15\%) residing in 10 Amazonian amerind villages. The distribution of these objects is discussed in CHERNELA \& THATCHER (1989).

\section{Parasite Distribution}

As shown in Figure 1, between $46 \%$ and $100 \%$ of each village's population was infected with Ascaris. Tukano villages consistently had the highest rates of Ascaris infection with percentages ranging from $56 \%$ to $100 \%$, and with a mean rate of $75 \%$. The lowest rates were found among the Maku groups who inhabited the forest and maintained little or no contact with Tukano. In one isolated Maku settlement, children 2-14 years of age showed an Ascaris infection rate as low as 34\%. The pattern of Ascaris infection discovered among Maku living in sedentary villages associated with Tukano settlements was similar to that of their Tukano neighbors, ranging from $65 \%$ to $100 \%$. In some cases, the Maku groups having a long-term association with Tukano riverine settlements had a higher rate of infection than the Tukanos with which they were associated.

\section{\% ASCARIS IN 12 AMAZON AMERIND VILLAGES}

\section{(498 persons)}

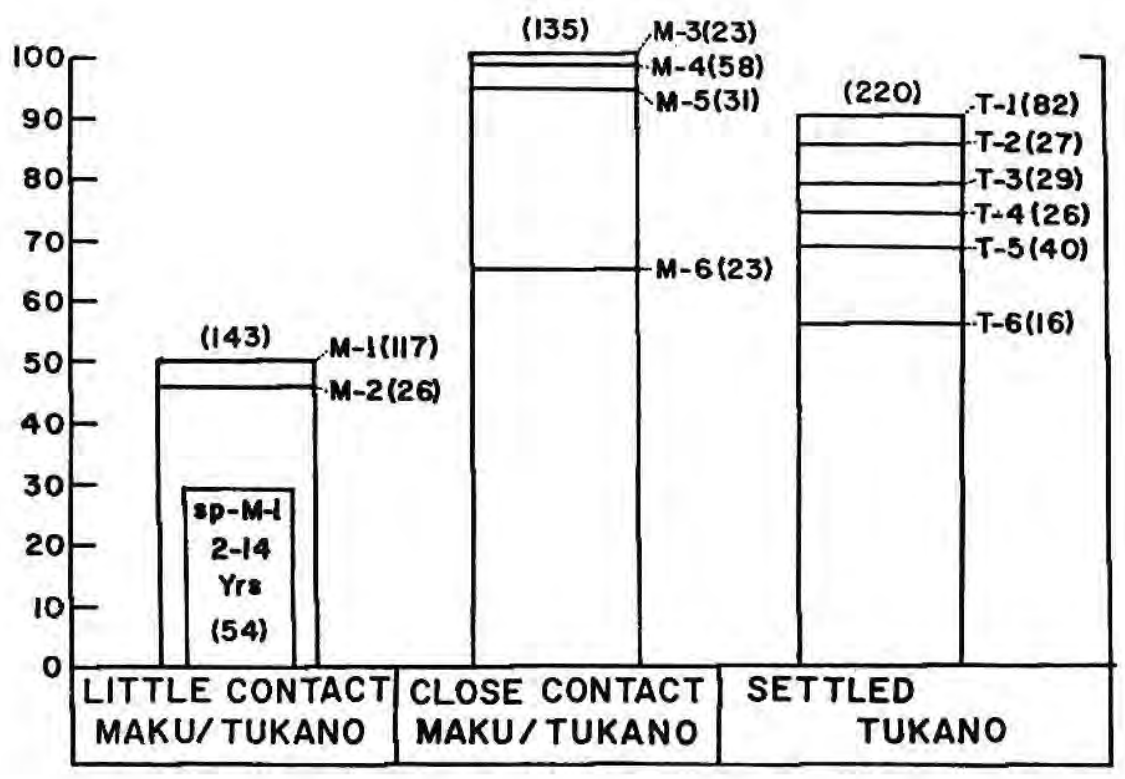

Figure 1. Percentages of Ascaris infection in residents of 12 Amazonian Amerindian villages. $\mathbf{M}=$ Maku; $\mathbf{T}=$ Tukano; Numbers in parentheses indicate the number of individuals in each sample. 
These figures indicate that the isolated and semi-nomadic Maku were in much better health, in terms of intestinal parasitism, than the sedentary Tukano. In the Maku village designated "M-1", $70 \%$ of the children and $50 \%$ of adults had no Ascaris at all. Although most members of the group had Entamoeba coli, this protozoan has never been implicated as a cause of any human disease. Most of these people also had Necator americanus, but at a very low intensity (10-30 EPG). Egg counts in this range indicate the presence of but one to five adult worms. This light an infection is unlikely to cause any inconvenience or symptoms of clinical disease.

The sedentary Tukano and the Maku in close contact, on the other hand, can be said to have been unhealthy from the standpoint of instestinal worm burden. From $55 \%$ to $100 \%$ of the people in these villages had heavy infections of Ascaris lumbricoides. Most also had Necator americanus and Trichuris trichiura. Eggs of these three nematodes were too numerous to count accurately in most of the samples, but they were estimated as light, moderate or heavy. Worm burdens for each of these species were estimated to be from 50 to 300 worms in each individual. All three are known to be pathogenic, with Necator and Trichuris being responsible for primary anemia from blood loss.

The protozoans, ciliophoran and unidentified nematodes in this population are probably of minimal importance in terms of health. Among the protozoans, only Entamoeba histolytica and Giardia lamblia are known pathogens and they were demonstrated in relatively few people. The high prevalence of Entamoeba coli, especially in the most isolated group, suggests that this may have been the native species of amoeba and that perhaps $E$. histolytica was originally introduced from the outside. The presence of the ciliophoran, Balantidium coli, in some villages could indicate an association with the domestic pig, since the species can pass directly from pig to man. We have recently found high prevalences of this parasite in peccaries and other wild mammals, however. Infections with Balantidium no doubt produce severe diarrhea, but they are probably transitory. As for the unidentified nematode eggs, they indicated only light infections (10 - 30 EPG) and we have no evidence that they produced any disease symptoms.

Proximity to western medical facilities produced no apparent effect. Two mission centers with clinics are located within the study area, in easy access of Tukano settlements. Despite this, parasite burdens found among the Tukano were consistently high. Moreover, "T-1", the Tukano village which showed the highest prevalence of $A s$ caris, was located closest to the mission center and clinic.

\section{DISCUSSION}

Evidence suggests that Ascaris was introduced into the New World by the arrival of Europeans, Africans and 
domestic pigs. It is widely accepted that the Ascaris of humans evolved from that of the pig. Neither pigs nor Ascaris occurred in the Americas before the conquest. Ova of Ascaris have been identified in at least eight European prehistoric sites. But, while helminth ova of other species have been found in Pre-Columbian mummies and coprolites, there is no evidence of $A s$ caris in the New World prior to the conquest (COCKBURN, 1977).

The archeological data are supported by observations among relatively unacculturated New World hunter-gatherers. For example, the lowest infection rate for Ascaris reported from a New World population not knowing sanitation came from a study conducted among the then newly-contacted, nomadic, hunting and gathering Kren-Akorore indians of the Brazilian Xingu (BARUZZI et al., 1977). These researchers reported an infection rate for Ascaris of only $15 \%$. In Malaya, a lower prevalence of Ascaris (11.6\%) was found among the semi-nomadic Negrito than among other, more acculturated, Malayan aborigines (DUNN, 1972).

The percentages of Ascaris infection shown here are among the highest and lowest ever recorded for a population without sanitation facilities. The semi-nomadic Maku, with little association and no co-residence with Tukano, showed a higher level of infection than the Kren-Akorore, but lower than the Tukano. This may be explained by a history of intermittent contact and a relatively nomadic settle- ment pattern. The data reported here suggest that aculturation alone is not enough to explain high infection rates, since both Makuan sub-groups share the same history of white contact. Rather, the sedentarism which often accompanies acculturation is the more signification factor. High percentages of parasitism were found both in sedentary Tukano populations and in their associated Maku settlements. Proximity to medical centers did not lower the incidence of Ascaris. These figures represent a gradation, then, from minimal to maximal infection, which can best be explained by environmental contamination associated with increased sedentarism.

The relationship between sedentarism and Ascaris infection changes when even minimal sanitation methods are introduced. FAUST's study (1958) of a poor, urban population with latrines in Cali, Colombia, showed an Ascaris infection rate of $48 \%$. Data from this and the Baruzzi study reveal that nomadic groups with little contact with whites no sanitary facilities have lower rates of Ascaris infection than an urban population with inadequate sanitary devices. Nomadic lifestyle decreases incidence of ascariasis more than rudimentary sanitation or medical facilities.

\section{CONCLUSION}

A number of variables including population density, the presence of intermediate hosts, humidity, temperature, the lifecycle of the helminth and 
the physical conditions of the soil determine whether or not a pathogen can persist within a population. Parasites with short life spans require constant reinfestation, while those with long life spans may persist for years in the absence of reinfestation. Consequently, although the semi-nomadic Maku have a high incidence of the long-lived (15 - 20 years) hookworm, Necator americanus, their semi-nomadic lifestyle prevents them from having the ongoing contact with contaminated soil that is necessary for maintaing high Ascaris levels. In Maku that have settled in villages, parasite intensity for all species soon rises to that of the neighboring Tukano.

The sedentary life of indian groups, such as the Tukano, makes them subject to this contamination, as is evidenced by the higher prevalence rates and intensities of parasites found among the Tukano villagers. On the other hand, a semi-nomadic band, such as a hunting group having only intermittent contact with permanent villages, tends to leave Ascaris behind as it moves to a new location.

\section{ACKNOWLEDGEMENTS}

Funding for this project was provided by a grant from the Conselho Nacional e Desenvolvimento Científico e Tecnológico through the Instituto Nacional de Pesquisas da Amazônia in Manaus, Amazonas, Brazil. The authors wish to thank Evaldete Ferraz, without whose assistance in field collections and preparation of specimes this work would not have been possible. Dr. Jorge Arias provided invaluable organizational and administrative support. Hugh Gladwin supplied important computer assistence.

\section{Literature Cited}

BARUZZI, R. G., MARCOPITO, L. F.; SERRA, N. S. C.; SOUZA, F. A. A.; STABiLE, C. 1977. The Kren Akorore: a recently contacted indigenous tribe. CIBA Foundation Symposium 49, Health and Disease in Tribal Societies. Elsevier Press. Amsterdam. pp. 179-211.

CHERNELA, J. M. 1983. Hierarchy and Economy of the Uanano (Kotiria) Speaking Peoples of the Middle Uaupes Basin. $\mathrm{Ph}$. D. Dissertation. Columbia University. University Microfilms International.

1985. Indigenous fishing in the neotropics: the Tukanoan Uanano of the blackwater Uaupes River Basin in Brazil and Colombia. Interciencia, 10(2):7886.

CHERNELA, J. M.; THATCHER, V. E. 1989. Comparison of parasite burdens in two native Amazonian populations. Medical Anthropology, 10:279-285.

COCKBURN, A. 1977. Where did our infections diseases come from? The evolution of infectious disease. CIBA Foundation Symposium 49, Health and Disease in Tribal Societies. Amsterdam. Elsevier Press. pp. 103-113.

DUNN, F. L. 1972. Intestinal parasitism in Malayan aborigines. Bull. World Health Org., 46(1):99-110.

FAUST, E. C. 1958. Epidemiology, diagnosis, and treatment of intestinal helminthiases in families of Ward Siloe, Cali, Colombia. Proc. World Cong. Gastroent., pp. 742-747.

HUGH-JONES, S. 1979. The Palm and the Pleaides. Cambridge University Press. England. 279 pp. 
MARTIN, L. K.; BEAVER, P. C. 1968. Evaluation of the Kato Thick Smear Technique for quantitative diagnosis of helminth infections. Am. J. Trop. Med. 17(3):383391.

PETERS, W.; GILLES, H. M. 1977. A Color Atlas of Tropical Medicine and Parasitology. Wolfe Medical Publications. London.

REID, H. 1979. Some Aspects of Movement, Growth, and Change Among the Hupdu
Indians of Brazil. Ph. D. Dissertation Cambridge University.

SILVERWOOD-COPE, P. 1972. A Contribution to the Ethnography of the Colombian Maku. Ph. D. Dissertation. Cambridge University.

WALSH. J. A.; WARREN, K. S. 1979. Selective primary health care - Interim strategy for disease control in developing countries. New England Journ. of Med., 301(18):967-974.

(Aceito para publicação em 24/06/93) 